Research Article

\title{
Study of clinical profile and risk factors associated with febrile urinary tract infection in preschool children
}

\author{
Kumar G. V.*, Aaron George, Viswanathakumar H. M.
}

Department of Pediatrics, Sri Siddhartha Medical College, Tumkur, Karnataka, India, pin code - 572107

Received: 17 December 2015

Accepted: 11 January 2016

*Correspondence:

Dr. Kumar G V,

E-mail: kumargowripura@yahoo.co.in

Copyright: (C) the author(s), publisher and licensee Medip Academy. This is an open-access article distributed under the terms of the Creative Commons Attribution Non-Commercial License, which permits unrestricted non-commercial use, distribution, and reproduction in any medium, provided the original work is properly cited.

\begin{abstract}
Background: Urinary tract infection (UTI) is a term applied to a variety of clinical conditions ranging from asymptomatic presence of bacteria in the urine to severe infection of the kidney with resultant sepsis. According to The National Institute for Health and Clinical Excellence (NICE) guidelines, urinary tract infection is defined by a combination of clinical features and the presence of bacteria in urine. The risk factors of UTI are age, gender, constipation, lack of circumcision, not taking anthelmintic and lack of toilet training.

Methods: This was across sectional study conducted on febrile preschool children, aged 3 to 6 years, who attended the outpatient department of Sri Siddhartha Medical College, Tumkur. Children with symptoms suggestive of UTI were enrolled, and a written informed consent was obtained from the parents. They were then interviewed using structured questionnaire for UTI.

Results: Out of 194 febrile preschool children, 21 cases were diagnosed to have UTI. Of the 194 cases, 102 (52.6\%) were females and $92(47.42 \%)$ were male. Out of 21 urine culture positive cases $14(66.6 \%)$ were females and 7 $(33.33 \%)$ were males. Occurrence of UTI was $7.6 \%$ in febrile males, $13.72 \%$ in febrile females and had the estimated overall occurrence is $10.8 \%$. Fever was present in all the cases. Besides fever, $47.62 \%$ children had increased frequency, $42.86 \%$ had excessive crying while micturition and $38.10 \%$ had chills and rigors. Foul smelling urine was present in $33.33 \%$ of children while $23.81 \%$ had abdominal pain. Out of 92 male children studied $16(17.39 \%)$ males had phimosis, of which $2(12.5 \%)$ developed urinary tract infections. Constipation was seen in $3(14.29 \%)$ children with UTI. Worm infestation was seen in $5(23.81 \%)$ children with UTI.

Conclusions: Children with urinary tract infections usually present with nonspecific symptoms and signs and hence a urine analysis and culture should always be part of an initial diagnostic evaluation of urinary tract infections. Female sex, constipation, not taking anthelmintic, lack of toilet training and phimosis are significant risk factors for febrile urinary tract infection in children.
\end{abstract}

Keywords: Urinary tract infection, Preschool children, Risk factors

\section{INTRODUCTION}

A urinary tract infection is defined as the presence of organisms in the urinary tract, which is usually sterile. Urinary tract infection (UTI) is a term applied to a variety of clinical conditions ranging from asymptomatic presence of bacteria in the urine to severe infection of the kidney with resultant sepsis. ${ }^{1}$ According to The National
Institute for Health and Clinical Excellence (NICE) guidelines, urinary tract infection is defined by a combination of clinical features and the presence of bacteria in urine. ${ }^{2}$ Over recent decades, the importance of UTI has been increasingly recognized, in particular the role of UTI as an occult cause of febrile illness in young children. Although UTIs do not occur with as great a frequency in children as in adults, they can be a source of 
significant morbidity in children. For reasons that are not yet completely understood, a minority of UTIs in children progress to renal scarring, hypertension and renal insufficiency. ${ }^{3}$ It is the third most common bacterial infection in children in developing countries after those of the gastrointestinal and respiratory tract. Because of nonspecific signs and vague symptoms in very young children, they remain unrecognized and therefore precise data on incidence and prevalence of UTI are not available. The commonest age for the occurrence of the first symptomatic UTI is the first year of life and males are affected more than females. ${ }^{4}$ During infancy, the risk of developing UTI is equal in boys and girls and thereafter higher in girls. ${ }^{5}$

Clinical presentation of UTI in children may be nonspecific and the appropriateness of certain diagnostic tests remains controversial. Studies have shown that UTI may often be missed on history and physical examination, and the decision to screen for UTI must balance the risk for missed infections with the cost and inconvenience of testing. ${ }^{6}$

The risk factors of UTI are numerous; they may be age, gender, constipation, lack of circumcision, inadequate water intake, not taking anthelmintic and lack of toilet training. As males are more likely to be born with structural abnormalities of the urinary tract, UTI is more common in their first six months of life. ${ }^{7}$ In preschool years symptomatic infections occur 10 to 20 times more frequently in girls than in boys. ${ }^{8}$ Constipation is a common problem of children worldwide. Estimates of the prevalence rate of functional constipation in the pediatric population have varied from $4 \%$ to $37 \%$. Urinary tract infection is a great morbidity in children. ${ }^{9,10}$ It encompasses renal damage as well as mortality of children. Many risk factors are responsible for initial urinary tract infection and recurrent urinary tract infection. The goal of our study is to know the clinical profile and risk factors which are associated with urinary tract infection in children.

\section{METHODS}

This was across sectional study conducted on febrile preschool children, aged 3 years to 6 years, who attended the outpatient department and inpatient department of Sri Siddhartha Medical College, Tumkur. Karnataka, India. Febrile children who attended outpatient department were submitted to preliminary screening interview to suspect urinary tract infection. Children with symptoms suggestive of urinary tract infections were enrolled, and a written informed consent was obtained from the parents. They were then interviewed using structured questionnaire for urinary tract infection. Urine samples of all symptomatic children were sent for urine routine microscopy and for urine culture. Data was statistically analyzed.

\section{RESULTS}

A total number of 194 febrile preschool children between 3 to 6 years of age who attended pediatric department were studied. Out of these patients, 21 cases were diagnosed to have UTI. Of the 194 cases of this study, $102(52.6 \%)$ were females and $92(47.42 \%)$ were male. Out of 21 urine culture positive cases 14 (66.6\%) were females and $7(33.33 \%)$ were males. Occurrence of UTI was $7.6 \%$ in febrile males, $13.72 \%$ in febrile females and had the estimated overall occurrence is $10.8 \%$ (Table-1).

Table 1: Occurrence of UTI in febrile children.

\begin{tabular}{|lllc|}
\hline Sex & $\begin{array}{l}\text { Total } \\
\text { number }\end{array}$ & $\begin{array}{l}\text { Number of urine } \\
\text { culture positive }\end{array}$ & $\begin{array}{l}\text { Percentage } \\
(\%)\end{array}$ \\
\hline Male & 92 & 7 & 7.6 \\
\hline Female & 102 & 14 & 13.72 \\
\hline Total & 194 & 21 & 10.80 \\
\hline
\end{tabular}

Fever was present in all the cases. Besides fever, $47.62 \%$ children had increased frequency, $42.86 \%$ had excessive crying while micturition and $38.10 \%$ had chills and rigors. Foul smelling urine was present in $33.33 \%$ of children while $23.81 \%$ had abdominal pain (Table 2).

Table 2: Symptomatology in Culture Positive Cases $(n=21)$.

\begin{tabular}{|lll|}
\hline Symptoms & $\begin{array}{l}\text { Urine culture } \\
\text { positive cases } \\
(\mathbf{n = 2 1 )}\end{array}$ & $\begin{array}{l}\text { Percentage } \\
(\boldsymbol{\%})\end{array}$ \\
\hline Vomiting & 4 & 19.05 \\
\hline Chills and rigors & 8 & 38.10 \\
\hline Increased frequency & 10 & 47.62 \\
\hline $\begin{array}{l}\text { Passing high colored } \\
\text { urine }\end{array}$ & 2 & 9.52 \\
\hline
\end{tabular}

Table 3: Risk factors associated with UTI in children.

\begin{tabular}{|lll|}
\hline Risk factors & Number & Percentage (\%) \\
\hline Constipation & 3 & 14.29 \\
\hline Poor toilet habits & 4 & 19.05 \\
\hline Pin worm infestation & 5 & 23.81 \\
\hline Female & 14 & 66.66 \\
\hline
\end{tabular}

Out of 92 male children studied $16(17.39 \%)$ males had phimosis, of which $2(12.5 \%)$ developed urinary tract infections. Constipation was seen in $3(14.29 \%)$ children with UTI. Worm infestation was seen in $5(23.81 \%)$ children with UTI (Table 3). 
Table 4: Various studies showing prevalence of urinary tract infection in febrile children.

\begin{tabular}{|c|c|c|c|c|}
\hline Sr. No. & Author (year) & Age of population & $\begin{array}{l}\text { No. of children } \\
\text { studied }\end{array}$ & Prevalence \\
\hline 1. & Roberts et $^{11}{ }^{11}$ & $0-2$ years & 193 & 4.1 \\
\hline 2. & Bonadio $^{12}$ & $0-1$ year & 265 & 5.53 \\
\hline 3. & Hoberman $^{13}$ et al & $0-1$ year & 945 & 5.3 \\
\hline 4. & Lin et $\mathrm{al}^{14}$ & $0-1$ year & 129 & 13.6 \\
\hline 5. & Krober et al $^{15}$ & $0-12$ years & 182 & 11 \\
\hline 6. & Schwartz et al ${ }^{16}$ & 0-3 Months & 463 & 18.3 \\
\hline 7. & Stanley et al ${ }^{17}$ & $0-1$ years & 92 & 27 \\
\hline 8. & Ashok C et al ${ }^{18}$ & 3-6 years & 500 & 4 \\
\hline
\end{tabular}

\section{DISCUSSION}

Urinary tract infection is a common, potentially serious and often occult bacterial infection of childhood. Urinary tract infection causes acute morbidity as well as long term sequelae including hypertension and impaired renal function. In most studies incidence of UTI is more in females than males. In the present study $10.8 \%$ of the children had urinary tract infections, with $13.72 \%$ of the females and $7.6 \%$ of the males studied having urine culture positive. The prevalence of UTI from various studies varies from $3 \%$ to $27 \%$. The present study also falls in the range with $10.80 \%$ of the children studied having urinary tract infection (Table 4).

Females are more prone to urinary tract infections than males. Hellstrom et al found that $8.4 \%$ of girls and $1.75 \%$ of boys aged up to 7 years had UTI. ${ }^{19}$ Hoberman et al ${ }^{13}$ and Roberts et $\mathrm{al}^{11}$ reported statistically significant increase in UTI in febrile female children. In the present study $13.72 \%$ of the females studied had culture positive UTI while $7.6 \%$ of the males had UTI.

The present study considered only febrile children. Increased frequency of micturition was seen in $47.62 \%$ of the cases and is the most common symptom, besides fever. Pain or excessive crying while micturition was seen in $42.86 \%$ of children. Foul smelling urine in $33.33 \%$ of children. Abdominal pain was present in $23.81 \%$ and vomiting in $19.05 \%$. Smellie et $\mathrm{al}^{20}$ found $28 \%$ of children to have abdominal or loin pain. Hoberman et $\mathrm{al}^{13}$ showed vomiting in $40 \%$ and diarrhea in $30 \%$ of the children. Craig et $\mathrm{al}^{21}$ showed vomiting in $42 \%$, diarrhea in $21 \%$, Dysuria in $15 \%$, Foul smelling urine in $13 \%$, abdominal pain in $13 \%$ and increased frequency in $10 \%$. In the present study the risk factors were female children $(66.66 \%)$, constipation (14.29\%), worm infestation $(23.81 \%)$ and poor toilet habits $(19.05 \%)$. Phimosis was seen in $28.57 \%$ of the male children who had UTI. Pradeep Sivaraj et al study showed $12.7 \%$ of the children had constipation, $73.4 \%$ of the children had improper toilet training and phimosis was seen in $25.3 \%$ of the children who had UTI. ${ }^{22}$

\section{CONCLUSION}

Urinary tract infection should always be kept in mind while evaluating a child with fever, especially in the younger age groups. Children with urinary tract infections usually present with nonspecific symptoms and signs and hence a urine analysis and culture should always be part of an initial diagnostic evaluation of urinary tract infections. Female sex, constipation, not taking anthelmintic, lack of toilet training and phimosis are significant risk factors for febrile urinary tract infection in children.

\section{Funding: No funding sources}

Conflict of interest: None declared

Ethical approval: The study was approved by the Institutional Ethics Committee

\section{REFERENCES}

1. Tanagho EA, Mcaninch JW. Bacterial Infections of the genitourinary tract. Smith's General Urology. $16^{\text {th }}$ ed. United States of America: McGraw-Hill Companies Inc. 2004:203-227.

2. National Institute for Health and Clinical Excellence (NICE). Urinary tract Infections. 2007 August. NICE clinical guideline 54. Available: http:// www.nice.org.uk/cg054. Accessed on 10 December 2015.

3. Quigley R. Diagnosis of urinary tract infections in children. Curr Opin Pediatr. 2009;21(2):194-8.

4. Eider JS. Urinary tract infection. In Nelson Textbook of Pediatrics. $19^{\text {th }}$ ed. Saunders Publishers. 2012:1829-1834.

5. Srivasta, Bagga A. Pediatric Nephrology. $5^{\text {th }}$ ed. Inida: Jaypee Brothers, Medical Publishers. 2011:235-250.

6. Roberts KB. Urinary Tract Infection: clinical practice guideline for the diagnosis and management of the initial UTI in febrile infants and children 2 to 24 months. Pediatrics. 2011;128(3):595-610.

7. Shaw KN, McGowan KL, Gorliek MH, Schwartz JS. Screening for urinary tract infection in infants in the emergency department: which test is best? Pediatrics. 1998;101(6):E1. 
8. Schlager TA. Urinary tract infections in infants and children. Infect Dis Clin North Am. 2003;17(2):35365.

9. Van der Wal MF, Benninga MA, Hirasing RA. The prevalence of encopresis in a multicultural population. J Pediatr Gastroenterol Nutr. 2005;40(3):345-8.

10. De AraújoSant, Anna AM, Calçado AC. Constipation in school aged children at public schools in Rio de Janeiro, Brazil. J Pediatr Gastroenterol Nutr. 1999;29(2):190-3.

11. Roberts KB, Charney E, Sweren R, Ahonkhai V, Bergman D, Coulter M, et al. Urinary tract infection in infants with unexplained fever: a collaborative study. J Pediatr. 1983;103:864-7.

12. Bonadio WA. Prevalence of urinary tract infection in febrile infants. Pediatr Emerg Care. 1987;3:75-8.

13. Hoberman A, Wald ER, Reynolds EA, Penchansky L, Charron M. Pyuria and bacteriuria in urine specimens obtained by catheter from young children with fever. J Pediatr. 1994;124:513-9.

14. Lin DS, Huang SH, Lin CC, Tung YC, Huang TT, Chiu NC, et al. Urinary tract infection in febrile infants younger than eight weeks of age. Pediatrics. 2000;105(2):E20.

15. Krober MS, Bass YW, Powell JM, Smith FR, Seto DS. Bacterial and viral pathogens causing fever in infants less than 3 months old. Am J Dis Child.1985;139(9):889-2.

16. Schwartz S, Raveh D, Toker O, Segal G, Godovitch $\mathrm{N}$, Schlesinger Y. A week-by-week analysis of the low-risk criteria for serious bacterial infection in febrile neonates. Arch dis child. 2009;94(4):287-92.

17. Rachel S, Pagon Z, Bachur R. Hyperpyrexia among infants younger than 3 months. Pediatric emergency care. 2005;21(5):291-4.

18. Ashok C, Kumar GV, Viswanathakumar HM. Study of the prevalence and clinical profile of urinary tract infection in febrile children aged 3-6 years who attended paediatric outpatient department in a teritiary care hospital. Intern $\mathbf{J}$ Health Sci Res. 2013;3(2):1-5.

19. Hellstorm A, Hanson E, Hansson S, Hjalmas K, Jodal U. Association between urinary symptoms at 7 years old and previous urinary tract infection. Arch Dis Child. 1991;66:232-4.

20. Smellie J M, Normand IC. Urinary infections in children. Postgrad Med J. 1985;61(720):895.

21. Craig J, Irwing L, Knight J, Sureshkumar P, Roy L. Symptomatic urinary tract infection in preschool Australian children. J Pediatr Child Health. 1998;34(2):154-9.

22. Sivaraj P, Pradhan S, Beriha SS, Barik RR, Tago N, Das L, Mohanty AK. Study of risk factors associated with febrile urinary tract infection in children. Sri Lanka J Child Health. 2015;44(3):1436.

Cite this article as: Kumar GV, George A, Viswanathakumar HM. Study of clinical profile and risk factors associated with febrile urinary tract infection in preschool children. Int J Contemp Pediatr 2016;3:243-6. 